\title{
Are blank cartridge guns really harmless?
}

\author{
İsmail Gülşen, M.D., ${ }^{1}$ Hakan Ak, M.D., ${ }^{2}$ Enver Sosuncu, M.D., ${ }^{1}$ Mehmet Deniz Bulut, M.D. ${ }^{3}$
}

${ }^{1}$ Department of Neurosurgery, Yuzuncu Yıl University Faculty of Medicine, Van

${ }^{2}$ Department of Neurosurgery, Bozok University Faculty of Medicine, Yozgat

${ }^{3}$ Department of Radiology, Yuzuncu Yıl University Faculty of Medicine, Van

\begin{abstract}
Blank cartridge guns are devices that discharge sound and gas, but no bullet or shot. These devices are very similar to real guns in the form of their external design and the sound generated during their firing. Although it is widely held in society that these devices are harmless, reports from Turkey and the world have shown that these guns are not entirely innocent. Herein, we present a 26-year-old male with a head injury due to gunshot from a blank cartridge. The purpose of this presentation is to emphasize that these devices are not harmless, contrary to common public opinion.
\end{abstract}

Key words: Blank cartridge gun; decompressive craniectomy; epidural hematoma; pneumatic effect; subdural hematoma.

\section{INTRODUCTION}

Blank cartridge guns are devices that discharge sound and gas flares, but no bullet or shot. Contrary to the widely accepted opinion, these guns are not harmless. Morbidity and mortality cases caused by these guns are increasing daily. Various types of injuries have been reported in the literature. ${ }^{[1-7]}$ In particular, head trauma due to these guns is an important cause of morbidity and mortality. ${ }^{[1,5-7]}$

Herein, we present a new case of head injury due to the firing of a gun with a blank cartridge, with suicidal intent.

\section{CASE REPORT}

A 26-year-old male admitted to the emergency room with head injury by gunshot from a blank cartridge. He was intubated upon admittance to the emergency room. The physical examination revealed skin defect and burn measuring $2 \times 3 \mathrm{~cm}$

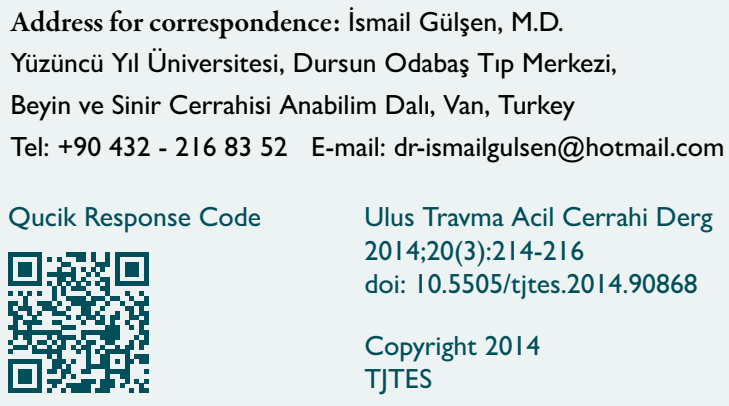

on the right temporal region. Glasgow coma scale (GCS) was 6 (EIVIM4). Light reflex was positive bilaterally; however, the right pupil was dilated slightly. Brain computed tomography (CT) revealed a fragmented displaced fracture of the right temporal bone, epidural and subdural hematoma $5 \mathrm{~mm}$ in thickness and intracerebral hematoma measuring $4 \times 5 \mathrm{~cm}$ on the same side, and II $\mathrm{mm}$ midline shift from right to left (Fig. Ia). The patient underwent immediate surgery. During the operation, bone fragments, some of which showed parenchymal invasion, were cleaned. Irregular tears on the dura were observed at multiple sites. The bone defect was extended with minimal craniectomy. The epidural and subdural hematoma was drained. Dura was repaired with galea graft. The patient was followed in the intensive care unit postoperatively. GCS was 7 (E2VIM4). Anisocoria improved in the early period. Thirty-six hours postoperatively, anisocoria recurred, and brain CT was taken, which revealed very dense edema on the right frontotemporal region and midline shift (Fig. Ib). The patient was re-operated, and decompressive craniectomy was performed. The dura was re-opened and duraplasty was extended. Bone flap was embedded in the abdomen. The patient showed an uneventful recovery after the re-operation. He was discharged without any neurologic deficit 10 days after the re-operation (Fig. Ic).

\section{DISCUSSION}

Blank cartridge guns were first used in the Prussian army for educational purposes. ${ }^{[5]}$ These guns fire sound and gas flares, but no bullet or shot. They have a metal hoop that prevents ejection of the contents of the hive from the barrel. These 
guns are used worldwide as a weapon of defense with the intent of threat. They produce a significant noise with a small amount of gunpowder or nitrocellulose. ${ }^{[4]}$ These guns cannot be used in sportive activities or hunting and do not provide security. These properties may lead us to consider that the aims of obtaining and carrying them might be due to passion or malice. These guns are used in various crimes, such as kidnapping, and for the purposes of threats, forced bondage securities, murder, exposure, and firing in residential areas. They are often fired at weddings and football games, and can lead to panic and fear among those in the immediate surroundings due to the noise generated. ${ }^{[8]}$
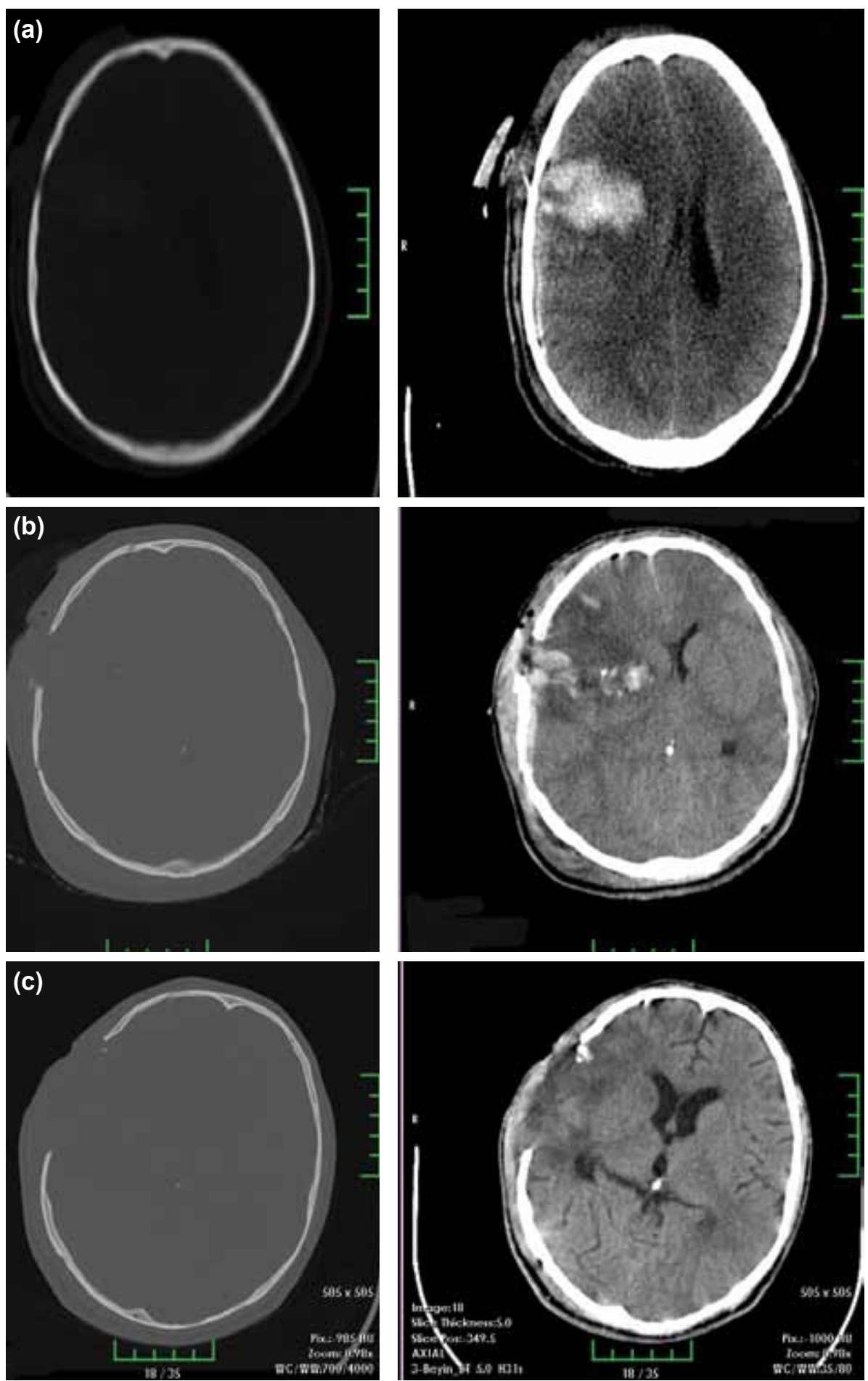

Figure 1. (a) Axial CT image of the brain at admission showing fragmented fractures in the right temporal region, intracerebral hematoma, and midline shift. (b) Axial CT image of the brain showing craniectomy defects, intracerebral edema and midline shift. (c) Axial CT image of the brain before the patient's discharge. 
In Turkey, the legal transactions regarding blank cartridges are done in accordance with the law legislated in 2008, according to which, these guns may be owned by individuals who have not been convicted on firearms and knives (related with law 6136), who have no history of imprisonment for more than one year for a deliberately committed crime, and who are older than 18 years of age. Thus, it is very easy to supply these guns compared with firearms. ${ }^{[1]}$

Conducted criminological studies have shown that the pressure at the tip of the barrel can reach up to 100-200 bars during discharge. This pressure may provide the energy necessary for penetrating the skin, and thus may lead to lifethreatening injuries, especially when fired at close range. ${ }^{[6]}$ Various organ injuries due to these guns have been reported, and include head trauma and jugular venous, abdominal, and intra-oral injuries. ${ }^{[1-5]}$ Among these injuries, head injuries in particular have been reported to be mortal. ${ }^{[7]}$ Fortunately, mortal head injuries due to the pneumatic effect of these guns are rare. Bone fractures have also been reported in the literature. ${ }^{[5]}$ In our case, the patient shot himself using his right hand, with the gun aimed at his right temporal region, with the intent of suicide, and he thus was found to have fragmented bone fractures at the same localization. Giese et al..$^{[5]}$ reported the occurrence of intracerebral hematoma in their case series. Our case also had an intracerebral hematoma of $4 \times 5 \mathrm{~cm}$ in diameter. Buyuk et al. ${ }^{[7]}$ reported two mortal cases. In a recent report, Çelik et al. ${ }^{[1]}$ reported a lethal brain injury caused by a blank cartridge pistol. They discharged the patient with intact neurological status. Our patient was also discharged with intact neurological examination.
In conclusion, as is shown in the literature and in our case, blank cartridge guns are not harmless and may lead to serious injuries, even death. Morbidity and mortality from such trauma may be seen with increased frequency in the future due to the ease with which these guns can be acquired. We believe that the current laws related to these guns should be revised.

Conflict of interest: None declared.

\section{REFERENCES}

1. Çelik Ö, Ekşi MŞ, Dağçınar A, Bayri Y, Konya D, Ziyal Mİ. Lethal brain injury caused by a blank cartridge pistol. [Article in Turkish] Journal of Neurological Sciences 2013:30;451-4.

2. İynen İ, Söğüt Ö, Şan İ, Kaya H, Bozkuş F. Suicidal injury caused by blank-firing gun. JAEMCR 2011:2;39-41.

3. Korkmaz Ö, Y1lmaz HG, Taçyılmaz İ. Abdominal trauma due to blank cartridge guns. [Article in Turkish] Turk J Emerg Med 2006;6:66-8.

4. İkizceli İ, Avşaroğlulları L, Sözüer EM, Özdemir Ç, Tuğcu H, Sever H, et al. Juguler vein gunshot injury from blank cartridges. [Article in Turkish] Ulus Travma Acil Cerrahi Derg 2005;11:254-8.

5. Giese A, Koops E, Lohmann F, Westphal M, Püschel K. Head injury by gunshots from blank cartridges. Surg Neurol 2002;57:268-77.

6. Clarot F, Vaz E, Papin F, Clin B, Vicomte C, Proust B. Lethal head injury due to tear-gas cartridge gunshots. Forensic Sci Int 2003;137:45-51.

7. Buyuk Y, Cagdir S, Avsar A, Duman GU, Melez DO, Sahin F. Fatal cranial shot by blank cartridge gun: two suicide cases. J Forensic Leg Med 2009;16:354-6.

8. Bozdemir A. Kuru sıkı ve gaz tabancaları serüveni. Çağın Polisi Dergisi, Vol.19, 2002. http://www.caginpolisi.com.tr/kuru-siki-ve-gaz-tabancalari-seruveni/.05.01.2014.

\title{
OLGU SUNUMU - ÖZET
}

\author{
Kurusıkı silahlar gerçekten zararsız $\mathrm{m} ı$ ? \\ Dr. İsmail Gülşen, ${ }^{1}$ Dr. Hakan Ak, ${ }^{2}$ Dr. Enver Sosuncu, ${ }^{1}$ Dr. Mehmet Deniz Bulut ${ }^{3}$ \\ ${ }^{1}$ Yüzüncü Yıl Üniversitesi Tıp Fakültesi, Beyin ve Sinir Cerrahisi Anabilim Dalı, Van \\ ${ }^{2}$ Bozok Üniversitesi Tıp Fakültesi, Beyin ve Sinir Cerrahisi Anabilim Dalı, Yozgat \\ ${ }^{3}$ Yüzüncü Yıl Üniversitesi Tıp Fakültesi, Radyoloji Anabilim Dalı, Van
}

Kuru sıkı silahlar mermi çekirdeği fırlatmaksızın ses ve gaz fişekleri ateşleyen silahlardır. Bu silahların ateşleme sırasında, dış görünümü ve sesi gerçeklerinden farksızdır. Toplulumuzda bu silahların, zarasız olduğuna dair inanış hakimken, literatürlerde bildirilen olgulara baktığımızda sanıldığı kadar masum olmadıklarıı görmekteyiz. Bu yazıda kuru sıkı silah ile kafa travması geçiren 26 yaşındaki hastayı sunarak kuru sıkı silahların zararlı silahlar olduklarını göstermeyi amaçladık.

Anahtar sözcükler: Dekompresif kraniotomi; epidural hematom; kuru sıkı silah; pnomotik etki; subdural hematom.

Ulus Travma Acil Cerrahi Derg 2014;20(3):214-216 doi: 10.5505/tjtes.2014.90868 